\title{
Effects of Thermocycling and Light Source on the Bond Strength of Metallic Brackets to Bovine Teeth
}

\author{
Ana Rosa COSTA ${ }^{1}$ \\ Américo Bortolazzo CORRER ${ }^{1}$ \\ Regina Maria PUPPIN-RONTANI ${ }^{2}$ \\ Silvia Amélia Scudeler VEDOVELLO ${ }^{3}$ \\ Heloísa Cristina VALDRIGHI ${ }^{3}$ \\ Lourenço CORRER-SOBRINHO ${ }^{1}$ \\ Mário VEDOVELLO FILHO ${ }^{3}$
}

\author{
${ }^{1}$ Department of Restorative Dentistry, Dental Materials Division, Piracicaba Dental School, \\ UNICAMP - University of Campinas, Piracicaba, SP, Brazil \\ ${ }^{2}$ Department of Pediatric Dentistry, Piracicaba Dental School, \\ UNICAMP - University of Campinas, Piracicaba, SP, Brazil \\ ${ }^{3}$ Department of Orthodontics, Graduate Program in Orthodontics, UNIARARAS - University of Araras, Araras, SP, Brazil
}

\begin{abstract}
This study evaluated the effects of thermocycling and different light sources on the bond strength of metallic brackets to bovine tooth enamel using an adhesive resin. Bovine teeth were etched with 35\% phosphoric acid gel for 20 s. After application of primer, metallic brackets were bonded to the buccal surface using Transbond XT, forming 8 groups $(n=20)$, depending on the light source used for photoactivation (AccuCure 3000 argon laser - 20 s, Apollo 95E plasma arc - 12 s, UltraLume 5 LED - 40 s and XL2500 halogen light - $40 \mathrm{~s}$ ) and experimental conditions without (Groups 1 to 4 ) or with thermocycling (Groups 5 to 8). Shear bond testing was carried out after $24 \mathrm{~h}$ of distilled water storage (Groups 1 to 4 ) or storage and thermocycling in distilled water (groups 5 to 8 ; 1,500 cycles $\left.-5^{\circ} / 55^{\circ} \mathrm{C}\right)$. Data were subjected to two-way ANOVA and Tukey's test $(\alpha=0.05)$. The Adhesive Remnant Index (ARI) was evaluated at $\times 8$ magnification. No significant differences $(p>0.05)$ in bond strength were found when the conditions without and with thermocycling were compared for any of the light sources. No significant differences $(p>0.05)$ in bond strength were found among the light sources, irrespective of performing or not thermocycling. There was a predominance of ARI scores 1 in all groups. In conclusion, light sources and thermocycling had no influence on the bond strength of brackets to bovine enamel.
\end{abstract}

Key Words: Light source, shear bond strength, bonding, thermocycling.

\section{INTRODUCTION}

Orthodontic brackets are routinely bonded by using light-cured materials. With them, the clinician has control of working time, more accurate bracket placement, easy removal of excess and immediate insertion of the orthodontic archwire (1).

Different light sources are currently available for photoactivation (2-9) and they should provide adequate polymerization the light-activated materials. Quartztungsten-halogen (QTH) and light-emitting diodes (LEDs) use irradiation times of 20 to $40 \mathrm{~s}(10,11)$, while plasma arc light (PAC) and lasers were introduced as an alternatives for fast polymerization $(12,13)$.

On the other hand, bracket-bonding failure sometimes during the stages of treatment due to heavy forces produced by an archwire. In addition, light-cured materials are subjected to thermal changes in the oral cavity. Thermocycling has been used to determine if temperature variations produced stresses in the lightcured materials that might influence on the bond strength (14). In Orthodontics, thermocycling regimens between 500 and 6,000 cycles have been used (14-18).

However, literature is still not conclusive about the effectiveness of different light-curing units, especially 
after thermocycling. This study evaluated the effects of thermocycling and different light sources (QTH, LED, PAC or laser) on the bond strength of metallic orthodontic brackets to bovine tooth enamel using an adhesive resin. The hypotheses tested were that there are (1) significant differences in the bond strength among the light sources, and (2) significant differences after thermocycling.

\section{MATERIAL AND METHODS}

One hundred sixty bovine mandibular incisors were collected, embedded in autopolymerizing acrylic resin (Clássico Produtos Odontológicos, São Paulo, SP, Brazil) in polyvinyl chloride tubes (Tigre, Joinvile, SC, Brazil), with the buccal face of parallel to the tube height, with the cementoenamel junction located $3 \mathrm{~mm}$ above the acrylic resin. The buccal face of all teeth was cleaned with a rotational brush (Gaúcha Fornituras, Porto Alegre, RS, Brazil) and nonfluoridated pumice-water slurry (S.S. White, Petrópolis, RJ, Brazil) for $10 \mathrm{~s}$, rinsed with air-water spray for $10 \mathrm{~s}$ and dried with air for $10 \mathrm{~s}$.

The middle third of the buccal face of all teeth were etched using $35 \%$ phosphoric acid gel (3M ESPE, St. Paul, MN, USA) for $20 \mathrm{~s}$, rinsed with air-water spray for $20 \mathrm{~s}$, dried with air for $20 \mathrm{~s}$, and the teeth were divided into 8 groups $(n=20)$, according to the light source used and whether or not they were subjected to a thermocycling regimen (Table 1). One layer of a primer (3M Unitek, Monrovia, CA, USA) was applied on the etched area of buccal face of the teeth. After that, stainless steel standard maxillary incisor brackets (Synergy; Rocky Mountain Orthodontics, Denver, CO, USA) were positioned and firmly bonded with Transbond $\mathrm{XT}$ light-cured bonding resin (3M Unitek). A microbrush was used to remove excess.

Light-activation was carried out with 4 exposures on each side of the bracket with total exposure times

Table 1. Groups according to light sources or thermocycling.

\begin{tabular}{lcc}
\hline \multirow{2}{*}{ Light source } & \multicolumn{2}{c}{ Thermocycling } \\
\cline { 2 - 3 } & No & Yes \\
\hline AccuCure 3000 argon laser (laser) & Group 1 & Group 5 \\
Apollo 95E plasma arc (PAC) & Group 2 & Group 6 \\
UltraLume 5 (LED) & Group 3 & Group 7 \\
$\begin{array}{lll}\text { XL2500 quartz-tungsten-halogen } \\
\text { (QTH) }\end{array}$ & Group 4 & Group 8 \\
\hline
\end{tabular}

20, 12, 40 and $40 \mathrm{~s}$ for AccuCure 3000 (LaserMed, West Jordan, UT, USA), Apollo 95E (DMD, Westlake, CA, USA), UltraLume 5 (Ultradent, South Jordan, UT, USA) and XL 2500 (3M ESPE), with power density of 500, 1200, 1500 and $800 \mathrm{~mW} / \mathrm{cm}^{2}$, respectively. The radiant exposure was $10,14.4,60$ and $32 \mathrm{~J} / \mathrm{cm}^{2}$ for the Laser, PAC, LED and QTH, respectively. In total, 20 brackets were bonded in each group, totalizing 160 bonded brackets.

After the bonding procedures, all specimens (groups 1 to 8 ) were stored in distilled water at $37^{\circ} \mathrm{C}$ for $24 \mathrm{~h}$. After this period, the specimens of groups 5 to 8 were subjected to a thermocycling regimen in a thermal cycler (MSCT 3; Marnucci ME, São Carlos, SP, Brazil) totalizing 1,500 cycles in distilled water between 5 and $55^{\circ} \mathrm{C}$ with 30 -s dwell time in each bath and transfer time of $10 \mathrm{~s}$ between baths.

Shear bond testing was performed in a mechanical testing machine (Model 4411; Instron, Canton, MA, USA) with a knife-edged rod at a crosshead speed of $1.0 \mathrm{~mm} / \mathrm{min}$ until failure. A mounting jig was used to align the bracket-tooth interface parallel to the testing device. Bond strength values were calculated in MPa and analyzed by two-way ANOVA and Tukey's test $(\alpha=0.05)$.

After debonding, a stereomicroscope (Olympus Corp, Tokyo, Japan) was used to analyze the tooth and bracket surfaces under $\times 8$ magnification. The Adhesive Remnant Index (ARI) was used to classify the failure modes (19): 0, indicates that no bonding resin on the tooth; 1 , indicates that less than half of the bonding resin remained on the tooth; 2 , indicates that more than half of the bonding resin remained on the tooth and 3, indicates that all bonding resin remained on the tooth, with a distinct impression of the bracket mesh.

\section{RESULTS}

The shear bond strength mean values are shown in Table 2. No significant differences $(p>0.05)$ in bond strength were found when the conditions without and with thermocycling were compared for any of the light sources. There were no significant differences $(p>0.05)$ in bond strength among the light sources, irrespective of performing or not thermocycling. There was a predominance of ARI scores 1 in all groups (Table 3).

\section{DISCUSSION}

The first hypothesis tested in this study was 
rejected, as no significant differences were observed among the light sources regardless of the thermocycling condition. These findings are in agreement with those of previous studies, which also found no significant differences among different light sources $(2,5,9,20-22)$. However, a recent study has found significant differences among LED, QTH and PAC units (4).

According to Rueggeberg (23) photoactivation is dependent on the radiant exposure, which is the product of irradiance and exposure time. In this study, PAC $\left(14.4 \mathrm{~J} / \mathrm{cm}^{2}\right)$ and laser $\left(10 \mathrm{~J} / \mathrm{cm}^{2}\right)$ showed lower radiant exposure during photoactivation than LED $\left(60 \mathrm{~J} / \mathrm{cm}^{2}\right)$ and QTH $\left(32 \mathrm{~J} / \mathrm{cm}^{2}\right)$. However, the laser was effective for photoactivation probably because its emission spectrum is concentrated on the absorption peak of camphorquinone (at $468 \mathrm{~nm}$ ). In relation to the PAC, according to Gonçalves et al. (9), the absence of differences might be explained by the fact that a very

Table 2. Bond strength mean values (in $\mathrm{MPa}$ ) and standard deviations.

\begin{tabular}{lcc}
\hline Light sources & No Thermocycling & Thermocycling \\
\hline AccuCure 3000 argon laser (laser) & $8.82(1.2)$ A.a & $8.28(1.4)$ A.a \\
Apollo 95E plasma arc (PAC) & $8.64(1.4)$ A.a & $8.15(1.0)$ A.a \\
UltraLume 5 (LED) & $9.40(1.0)$ A.a & $9.10(1.2)$ A.a \\
XL2500 quartz-tungsten-halogen (QTH) & $8.93(1.1)$ A.a & $8.42(1.3)$ A.a \\
\hline
\end{tabular}

Same uppercase letters in the same row and lowercase letters in the same column indicate no statistically significant difference $(\mathrm{p}>0.05)$.

Table 3. Frequency distributions of the Adhesive Remnant Index (ARI) scores.

\begin{tabular}{lccccc}
\hline \multirow{2}{*}{ Light sources } & \multirow{2}{*}{ Thermocycling } & \multicolumn{5}{c}{ ARI Scores (\%) } \\
\cline { 3 - 6 } & & 0 & 1 & 2 & 3 \\
\hline \multirow{2}{*}{ AccuCure 3000 argon laser (laser) } & No & 3 & 9 & 5 & 3 \\
& Yes & 4 & 10 & 4 & 2 \\
Apollo 95E plasma arc (PAC) & No & 3 & 10 & 4 & 3 \\
& Yes & 2 & 9 & 5 & 4 \\
UltraLume 5 (LED) & No & 2 & 11 & 5 & 2 \\
XL2500 quartz-tungsten-halogen & Yes & 3 & 10 & 6 & 1 \\
(QTH) & No & 3 & 12 & 4 & 1 \\
\hline
\end{tabular}

The ARI scale has a range between 0 and 3. 0 , indicates that no bonding resin on the tooth; 1 , indicates that less than half of the bonding resin remained on the tooth; 2 , indicates that more than half of the bonding resin remained on the tooth and 3 , indicates that all bonding resin remained on the tooth, with a distinct impression of the bracket mesh. thin resin layer is necessary for bracket bonding and thus the differences in energy dose were probably not great enough to influence the bond strengths.

The durability of the bond between bracket/ bonding resin and teeth in clinical use must be evaluated. Thermocycling is used to determine if temperature might influence on the bond strength. employed to determine the (24), a decrease in the bond strengt by hydrolytic degradation of the interface components.

The second hypothesis tested was also rejected, as no significant differences were found between thermocycling and water storage for any of the curing conditions. These results agree with those of previous studies, which found no significant difference in bond strength after thermocycling $(14,16-18)$. It may be speculated that a larger number of cycles is necessary to permit accelerated simulation (16).

According to Reynolds (25), bond strength values between 6 to $8 \mathrm{MPa}$ are adequate for orthodontic applications under clinical conditions, which means that all groups in the present study had clinically acceptable bond strengths to resist forces during orthodontic treatment.

The results of ARI scores indicated that the majority of failures on debonding let less than half of the bonding resin on the tooth (scores 1 ). This is clinically advantageous because there would be less adhesive to remove from the tooth surface after debonding.

In summary, the present study demonstrated that thermocycling and light source were not decisive factors for the bond strength of brackets to tooth surfaces. Although the light sources had a similar performance with respect to bond strength, the use of high-intensity light-curing units is 
recommended to obtain effectiveness of polymerization of the bonding resin and care should be taken during bonding procedures, irrespective of the light source used. Future studies should also be carried out using regimens with a larger number of thermal cycles.

\section{RESUMO}

Este estudo avaliou o efeito da termociclagem e diferentes fontes de luz na resistência de união de bráquetes metálicos ao esmalte bovino utilizando uma resina adesiva. Dentes bovinos foram condicionados com ácido fosfórico $35 \%$ por 20 s. Após aplicação do primer, bráquetes metálicos foram colados na superfície bucal usando Transbond XT, formando 8 grupos $(n=20)$, dependendo das fontes de luz usadas para fotoativação (AccuCure 3000 argon laser - 20 s, Apollo 95E plasma arc - 12 s, UltraLume 5 LED - 40 s e XL2500 halogen light - $40 \mathrm{~s}$ ) nas condições experimentais sem (Grupos 1 a 4) ou com termociclagem (Grupos 5 a 8). O teste de resistência de união foi realizado após $24 \mathrm{~h}$ armazenados em água destilada (Grupos 1 a 4) ou armazenados e termociclados em água destilada (Grupos 5 a $8 ; 1500$ ciclos $-5^{\circ} / 55^{\circ} \mathrm{C}$ ). Os dados foram submetidos à Análise de Variância de duas vias e ao teste de Tukey $(\mathrm{p}<0,05)$. O Índice Remanescente do Adesivo (IRA) foi avaliado em aumento de 8 vezes. Nenhuma diferença significante $(p>0,05)$ na resistência de união foi encontrada quando as condições, sem ou com termociclagem foi comparado, para qualquer das fontes de luz. Nenhuma diferença significante $(p>0,05)$ na resistência de união foi encontrada entre as fontes de luz, independente de realizar ou não a termociclagem. O IRA mostrou predominância de escore 1 em todos os grupos. Em conclusão, as fontes de luz e a termociclagem não influenciaram na resistência de união do bráquete ao esmalte bovino.

\section{REFERENCES}

1. Sfondrini MF, Cacciafesta V, Scribante A, Klersy C. Plasma arc versus halogen light curing of orthodontic brackets: a 12-month clinical study of bond failures. Am J Orthod Dentofacial Orthop 2004;125:342-347.

2. Dall'Igna CM, Marchioro EM, Spohr AM, Mota EG. Effect of curing time on the bond strength of a bracket-bonding system cured with a light-emitting diode or plasma arc light. Eur J Orthod 2011;33:55-59.

3. Correr AB, Sinhoreti MA, Sobrinho LC, Tango RN, Schneider LF, Consani S. Effect of the increase of energy density on Knoop hardness of dental composites light-cured by conventional QTH, LED and xenon plasma arc. Braz Dent J 2005;16:218-224.

4. Cekic-Nagas I, Egilmez F, Ergun G. The effect of irradiation distance on microhardness of resin composites cured with different light curing units. Eur J Dent 2010;4:440-446.

5. Thind BS, Stirrups DR, Lloyd CH. A comparison of tungstenquartz- halogen, plasma arc and light-emitting diode light sources for the polymerization of an orthodontic adhesive. Eur J Orthod 2006;28:78-82.

6. Filipov IA, Vladimirov SB. Residual monomer in a composite resin after light-curing with different sources, light intensities and spectra of radiation. Braz Dent J 2006;17:34-38.

7. Park JK, Hur B, Ko CC, García-Godoy F, Kim HI, Kwon YH. Effect of light-curing units on the thermal expansion of resin nanocomposites. Am J Dent 2010;23:331-334.
8. Price RB, Labrie D, Rueggeberg FA, Felix CM. Irradiance differences in the violet $(405 \mathrm{~nm})$ and blue $(460 \mathrm{~nm})$ spectral ranges among dental light-curing units. J Esthet Restor Dent 2010;22:363-377.

9. Gonçalves PRA, Moraes RR, Costa AR, Correr AB, Nouer PRA, Sinhoreti MAC, et al.. Effect of etching time and light source on the bond strength of metallic brackets to ceramic. Braz Dent J 2011;22:245-248.

10. Swanson T, Dunn WJ, Childers DE, Taloumis LJ. Shear bond strength of orthodontic brackets bonded with light-emitting diode curing units at various polymerization times. Am J Orthod Dentofacial Orthop 2004;125:337-341.

11. Usumez S, Buyukyilmaz T, Karaman AI. Effect of light-emitting diode on bond strength of orthodontic brackets. Angle Orthod 2004; 74:259-263.

12. Talbot TQ, Blankenau RJ, Zobitz ME, Weaver AL, Lohse CM, Rebellato J. Effect of argon laser irradiation on shear bond strength of orthodontic brackets: an in vitro study. Am J Orthod Dentofacial Orthop 2000;118:274-279.

13. Klocke A, Korbmacher HM, Huck LG, Kahl-Nieke B. Plasma arc curing lights for orthodontic bonding. Am J Orthod Dentofacial Orthop 2002;122:643-648.

14. Bishara SE, Ostby AW, Laffoon JF, Warren J. Shear bond strength comparison of two adhesive systems following thermocycling. Angle Orthod 2007;77:337-341.

15. Faltermeier A, Müssig D. A comparative evaluation of bracket bonding with 1-, 2-, and 3-component adhesive systems. Am J Orthod Dentofacial Orthop 2007;132:144.e1-144.e5.

16. Gale MS, Darvell BW. Thermal cycling procedures for laboratory testing of dental restorations. J Dent 1999;27:89-99.

17. Trites B, Foley TF, Banting D. Bond strength comparison of 2 self-etching primers over a 3-month storage period. Am J Orthod Dentofacial Orthop 2004;126:709-716.

18. Yuasa T, Iijima M, Ito S, Muguruma T, Saito T, Mizoguchi I. Effects of long-term storage and thermocycling on bond strength of two self-etching primer adhesive systems. Eur J Orthod 2010;32:285-290.

19. Artun J, Berglund S. Clinical trials with crystal growth conditioning as an alternative to acid-etch enamel pretreatment. Am J Orthod 1984;85:333-340.

20. Oesterle LJ, Newman SM, Shellhart WC. Rapid curing of bonding composite with a xenon plasma arc light. Am J Orthod Dentofacial Orthop 2001;119:610-616.

21. Staudt CB, Mavropoulos A, Bouillaguet S, Kiliaridis S, Krejcid I. Light-curing time reduction with a new high-power halogen lamp. Am J Orthod Dentofacial Orthop 2005;128:749-754.

22. Yu HS, Lee KJ, Jin GC, Baik HS. Comparison of the shear bond strength of brackets using the LED curing light and plasma arc curing light: polymerization time. World J Orthod 2007;8:129-135.

23. Rueggeberg F. Contemporary issues in photocuring. Compend Contin Educ Dent Suppl 1999;4-15.

24. De Munck J, Van Landuyt K, Peumans M, Poitevin A, Lambrechts $\mathrm{P}$, Braem M, et al.. A critical review of the durability of adhesion of tooth tissue: methods and results. J Dent Res 2005;84:118-132.

25. Reynolds IR. Composite filling materials as adhesives in Orthodontics. Br Dent J 1975;138:83.

Received March 10, 2011 Accepted September 8, 2011 